
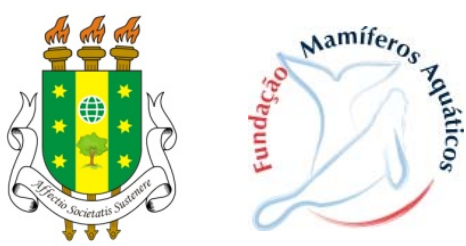

Natural:Resources

Journal homepage:

www.arvore.org.br/see

\section{AVALIAÇÃO DO IMPACTO AMBIENTAL CAUSADO PELO TURISMO ÀS TARTARUGAS MARINHAS NA PRAIA DE PORTO DE GALINHAS (PE)}

\section{RESUMO}

As tartarugas marinhas são répteis, de aproximadamente 220 milhões de anos, que surgiram no período triássico. No mundo existem sete espécies de tartarugas, destas, cinco aparecem no Brasil: Dermochelys coriácea, Chelonia mydas, Caretta, Eretmochelys imbricata, Lepidochelys olivacea, (SANCHES, 1999). Essas espécimes estão com risco de extinção, sendo protegidas por leis nacionais e internacionais de acordo com a União Internacional de Conservação da Natureza (IUCN). Avaliar e enumerar o impacto ambiental causado pelo desenvolvimento e turismo não sustentável, através de ações antrópicas responsáveis por estes impactos que atingem as tartarugas marinhas e seu ecossistema. Descrever formas de turismo sustentável, ecologicamente correto que preservem a vida destas espécies na praia de Porto de Galinhas - PE. A presente pesquisa realizou-se através de um amplo levantamento bibliográfico através de material impresso, digital, contido nas revistas científicas, artigos, livros, web que tratam deste assunto. Explorar através de procedimentos o meio ambiente danificando-o menos possível quanto ao turismo sustentável, já que poder político e o capitalismo se sobre põem diante do meio ambiente e dos animais. Nos locais de desova da tartaruga, existir a sinalização nas praias que impeça o deslocamento de pessoas e automóveis, as construções de casas, devido à iluminação artificial que desorienta as mesmas, neste período, preservando a fase de nascimento das tartarugas marinhas. As tartarugas marinhas são importantes elos da cadeia alimentar, como consumidores, atingem diversos níveis na cadeia. Nas ultimas décadas, elas veem sofrendo ameaça de extinção, principalmente pelo impacto ambiental negativo causado no seu habitat por ação antrópica. Preservar as espécies de animais e as das tartarugas marinhas é preservar a própria história da evolução da vida e do mundo.

PALAVRAS-CHAVE: Impacto Ambiental; Turismo; Tartaruga Marinha; Porto de Galinhas.
Natural Resources, Aquidabã, v.3, n.2, Set 2013.

ISSN 2237-9290

\section{SECTION: Anais do Congresso} Internacional de Ecotoxicologia Marinha (ECOMAR 2013)

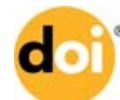

DOI: $10.6008 / E S S 2237-9290.2013 .002 .0015$

Gabriela Rayara Andrade Lima Sales de Oliveira

Instituto de Tecnologia de Pernambuco, Brasil http://lattes.cnpq.br/7900099553291294 rejanecosta@ufmg.br

Maria da Salete Horácio da Silva

Centro de Defesa do Saber Popular em Saúde, Brasil http://lattes.cnpq.br/9946387390285306 mshsilva@gmail.com

Received: 01/04/2013

Approved: 15/06/2013

Reviewed anonymously in the process of blind peer.

Referencing this:

OLIVEIRA, G. R. A. L. S.; SILVA, M. S. H.. Avaliação do impacto ambiental causado pelo turismo às tartarugas marinhas na Praia de Porto de Galinhas (PE). Natural Resources, Aquidabã, v.3, n.2, p.20, 2013. DOI: http://dx.doi.org/10.6008/ESS2237$\underline{9290.2013 .002 .0015}$ 